\title{
Activation of phenylpropanoid pathway in legume plants exposed to heavy metals. Part l. Effects of cadmium and lead on phenylalanine ammonia-lyase gene expression, enzyme activity and lignin content
}

\author{
Sylwia Pawlak-Sprada, Magdalena Arasimowicz-Jelonek, Magdalena Podgórska \\ and Joanna Deckert \\ Department of Plant Ecophysiology, Institute of Experimental Biology, Faculty of Biology, Adam Mickiewicz University, Poznań, Poland
}

\begin{abstract}
Species-specific changes in expression of phenylalanine ammonia-lyase (PAL) and lignin content were detected in roots of soybean (Glycine max L.) and lupine (Lupinus luteus L.) seedlings treated with different concentrations of cadmium $\left(\mathrm{Cd}^{2+}, 0-25 \mathrm{mg} / \mathrm{l}\right)$ or lead $\left(\mathrm{Pb}^{2+}, 0-350 \mathrm{mg} / \mathrm{l}\right)$. The stimulatory effect of both metals was observed in mRNA coding for PAL in soybean. In the case of lupine, changes of PAL mRNA level were dependent on the metal used: $\mathrm{Cd}^{2+}$ caused a decrease, whereas $\mathrm{Pb}^{2+}$ an increase of PAL transcript level. The activity of PAL was enhanced in both plant species at higher metal concentrations (15-25 mg/l of $\mathrm{Cd}^{2+}$ or $150-350 \mathrm{mg} / \mathrm{l}$ of $\mathrm{Pb}^{2+}$ ); however it was not directly correlated with PAL mRNA. This suggests a transcriptional and posttranscriptional control of PAL expression under heavy metals stress. In soybean, $\mathrm{Cd}^{2+}$ or $\mathrm{Pb}^{2+}$ treatment increased lignin content, while in lupine the effect was opposite. The decreased lignin accumulation in lupine roots in response to heavy metals, despite an increased PAL activity, suggests that the activated phenylpropanoid pathway was involved in the synthesis of secondary metabolites other than lignin.
\end{abstract}

Keywords: cadmium, gene expression, lead, lignin, lupine, phenylalanine ammonia-lyase (PAL), soybean

Received: 05 November, 2010; revised: 24 January, 2011; accepted: 08 March, 2011; available on-line: 19 April, 2011

\section{INTRODUCTION}

The contamination of soil with heavy metals, such as cadmium and lead, has become a serious environmental problem leading to toxic effects in plants and health hazard. Heavy metals trigger various stress reactions in plants, which depend on plant genotype, developmental stage as well as the concentration and the metal type. The plant responses may either lead to plant adaptation and resistance to the metal stress or result in severe plant damage and eventual death (Das et al., 1997; Sandalio et al., 2001; Seregin \& Ivanov, 2001; Patra et al., 2004; Deckert, 2005; Sharma \& Dubey, 2005). A coordinated network of molecular processes provides plant cells with multiple metal-detoxifying mechanisms and repair capabilities which allow plants to survive in metal-containing environments (Clemens, 2001; Cobbett \& Goldsbrough 2002; Shingu et al., 2005).

Earlier studies performed in our laboratory showed that lead $\left(\mathrm{Pb}^{2+}\right)$ and cadmium $\left(\mathrm{Cd}^{2+}\right)$ caused a growth in- hibition of lupine and soybean seedlings which was correlated with accumulation of the metals within plant cells and various stress responses. They included activation of antioxidant system (Rucińska et al., 1999; Sobkowiak et al., 2004; Pawlak et al., 2009), perturbation of the cell cycle, DNA damage (Deckert \& Gwóźdź, 1999; Sobkowiak \& Deckert, 2003; 2004; Rucińska et al., 2004) and induction of various proteins (Przymusiński \& Gwóźdź, 1999; Sobkowiak \& Deckert, 2006). The function of some of those proteins in the plant response to metals is still not known. One of the proteins induced by $\mathrm{Cd}^{2+}$ in soybean was identified as chalcone synthase (CHS; EC 2.3.1.74) (Sobkowiak \& Deckert, 2006). This result suggested an involvement of the phenylpropanoid pathway in the response of legume plants to metals. The gene coding for phenylalanine ammonia-lyase (PAL; EC 4.3.1.5), a key enzyme in the phenylpropanoid pathway, was also detected among $\mathrm{Cd}^{2+}$-induced genes in Brassica juncea (Fusco et al., 2005). On the other hand, a proteomic analysis of Arabidopsis thaliana exposed to $\mathrm{Cd}^{2+}$ and a study on $\mathrm{Pb}^{2+}$-regulated genes in Sesbania drummondi failed to detect an induction of any proteins or genes corresponding to the phenylpropanoid pathway enzymes (Roth et al., 2006; Srivastava et al., 2007). Those results were unexpected, as activation of PAL and an increase in lignin content are considered as common plant responses to various stress factors, including heavy metals (Jbir et al., 2001; Dixon et al., 2002; Janas et al., 2002; Mandre, 2002; Winkel-Shirley, 2002; Jouili \& Ferjani, 2003; Lin et al., 2005; Yang et al., 2007; Kovacik \& Klejdus, 2008). The expression of genes coding for both enzymes, PAL and CHS, has been analyzed under various stress conditions, but the knowledge on their regulation by metals in agronomically important plant species is limited.

In this study the expression of the gene coding for PAL, the activity of the enzyme, and lignin content were assessed in root seedlings of two legume species: soybean (Glycine max) and lupine (Lupinus luteus) exposed to cadmium $\left(\mathrm{Cd}^{2+}\right)$ or lead $\left(\mathrm{Pb}^{2+}\right)$. Unexpectedly, we observed opposite reactions of the two plant species to heavy metals. This calls into question the common belief that PAL activation and increased lignin accumulation are universal plant responses to abiotic stress.

e-mail: Joanna.Deckert@amu.edu.pl

Abbreviations: $\mathrm{CHS}$, chalcone synthase; $\mathrm{PAL}$, phenylalanine ammonia-lyase; RT-PCR, reverse transcription PCR 


\section{MATERIALS AND METHODS}

Plant material. Seeds of soybean (Glycine $\max$ L. cv. Nawiko) obtained from the Department of Genetics and Plant Breeding, Poznań University of Life Sciences, and yellow lupine (Lupinus luteus L. cv. Juno) were surface sterilized with $75 \%$ ethanol for $5 \mathrm{~min}$, followed by $1 \%$ sodium hypochloride for $10 \mathrm{~min}$, washed in water and germinated for $48 \mathrm{~h}$ on water-moistened filter paper in Petri dishes. The seedlings were than transferred to dishes containing $5 \mathrm{ml}$ of either distilled water (control), aqueous solution of $\mathrm{CdCl}_{2}$ containing $5,10,15,20$ or $25 \mathrm{mg} / \mathrm{l}$ of $\mathrm{Cd}^{2+}$ or aqueous solution of $\mathrm{Pb}\left(\mathrm{NO}_{3}\right)_{2}$ containing $50,100,150,200$ or $350 \mathrm{mg} / 1$ of $\mathrm{Pb}^{2+}$. The seedlings were incubated in the dark at $22{ }^{\circ} \mathrm{C}$ for $48 \mathrm{~h}$.

Determination of transcript level of phenylalanine ammonia-lyase gene $(P A L)$ by reverse transcription PCR (RT-PCR). Total RNA was extracted from 100 $\mathrm{mg}$ of frozen root tips (5-mm long) using the TRI ${ }^{\circledR}$ Reagent (Sigma) according to the manufacturer's instructions and then treated with deoxyribonuclease I, amplification grade (Sigma). Samples containing $1 \mu \mathrm{g}$ of RNA were used for reverse transcription with the RevertAid ${ }^{\mathrm{TM}}$ First Strand cDNA Synthesis Kit (Fermentas) and oligo $(\mathrm{dT})_{18}$ primer according to the manufacturer's procedure, in a total volume of $20 \mu \mathrm{l}$.

Primers for $P A L$ gene were designed by Primer3 Output software and were based on available soybean and lupine cDNA sequences (gi:257814) found in the NCBI (GenBank). We used ubiquitin as a housekeeping gene (gi:18779). The following primers were used:

- for PAL: primer I (5'-GCCATTGACTTGAGGCATT'T-3') and primer II (5'-GCACT'TGCCTTAGCT'T'T'TGC3-')

- for Ub (ubiquitin) for soybean: primer I (5'-GAAGTCGAAAGCTCCGACAC-3') and primer II (5'-TGT'T T'TGGGAACACATCCAA-3')

- for Ub (ubiquitin) for lupine: primer I (5'-TGGTGGCATGCAGATCT'T'TGT-3') and primer II (5'-AAGACGAAGACAAGGTGGAGT-3')

Two microliter aliquots of first strand cDNA were amplified with the use of $2 \times$ Master Mix (Fermentas) according to a previously described touch-down procedure (Sobkowiak \& Deckert, 2003 and 2004). The PCR reactions were performed as follows: one denaturation cycle of $3 \mathrm{~min}$ at $95^{\circ} \mathrm{C}, 35$ cycles of denaturation for $30 \mathrm{~s}$ at $95^{\circ} \mathrm{C}, 14$ cycles of primer annealing for $30 \mathrm{~s}$ at which temperature was decreased at each cycle by $1{ }^{\circ} \mathrm{C}$ from $68^{\circ} \mathrm{C}$ to $55^{\circ} \mathrm{C}$, followed by 21 cycles of annealing at $55^{\circ} \mathrm{C}$, and 34 cycles of elongation for $2 \mathrm{~min}$ at $72^{\circ} \mathrm{C}$. Final elongation was performed for $8 \mathrm{~min}$ at $72^{\circ} \mathrm{C}$. Amplified products were analyzed on $2 \%$ agarose gels and stained with ethidium bromide. The amplified DNA was quantified by densitometry using Multi Gauge V2.2 program (Fuji Film). All RT-PCRs were repeated three times, using three independent RNA samples.

Extraction and assay of phenylalanine ammonialyase (PAL) activity. The PAL (EC 4.3.1.5) activity was measured with a modified method of Cahill and McComb (1992). Root tips were homogenized on ice in a mortar with $0.1 \mathrm{M}$ Tris/ $\mathrm{HCl}$ buffer at $\mathrm{pH} 8.9$ containing $10 \mathrm{mM}$ mercaptoethanol, in a ratio of $4 \mathrm{ml}$ buffer for $300 \mathrm{mg}$ of plant tissue. Extracts were centrifuged at $15000 \times g$ at $4^{\circ} \mathrm{C}$ for $30 \mathrm{~min}$. Supernatants were used for measurement. The incubation mixture contained $80 \mathrm{mM}$ borate buffer ( $\mathrm{pH}$ 8.9), $30 \mathrm{mM}$ L-phenylalanine and $0.5 \mathrm{ml}$ enzymatic extract in a volume of $1.5 \mathrm{ml}$. After one hour of incubation in a water bath at $30^{\circ} \mathrm{C}$ the re- action was stopped by addition of $1.5 \mathrm{ml}$ of $2 \mathrm{M} \mathrm{HCl}$. The amount of trans-cinnamic acid formed was measured spectrophotometricaly at $290 \mathrm{~nm}$ using a UV-1202 Shimadzu spectrophotometer. The activity of the enzyme was expressed in $\mu$ mole of cinnamic acid formation per $1 \mathrm{mg}$ protein per hour. Protein content was assayed according to Bradford.

Determination of lignin content. Lignin content was measured according to a modified method of Doster and Bostock (1988). Root tips were extracted for $48 \mathrm{~h}$ with two one-milliliter portions of methanol per 1 $\mathrm{g}$ of tissue. Then the residue was dried in a desiccator and pulverized in a mortar. Twenty milligrams of dry tissue was mixed with $2 \mathrm{ml}$ of $2 \mathrm{M} \mathrm{HCl}$ and $0.5 \mathrm{ml}$ of thioglycolic acid. The samples were heated at $95^{\circ} \mathrm{C}$ for $4 \mathrm{~h}$ and centrifuged at $3000 \times g$ for 20 minutes. Pellets were washed twice with deionized water, extracted with $2 \mathrm{ml}$ of $0.5 \mathrm{M} \mathrm{NaOH}$ for $18 \mathrm{~h}$ at room temperature and separated by centrifugation at $15000 \times g$. The $\mathrm{NaOH}$ extract was collected and the precipitate was washed with $2 \mathrm{ml}$ of deionized water and centrifuged at $15000 \times g$. The obtained supernatant was added to the $\mathrm{NaOH}$ extract. Then the extract was acidified with $1 \mathrm{ml}$ of concentrated $\mathrm{HCl}$, left at $5^{\circ} \mathrm{C}$ overnight and centrifuged $(15000 \times \mathrm{g})$. The pellet was dissolved in $10 \mathrm{ml}$ of $0.5 \mathrm{M} \mathrm{NaOH}$ and centrifuged at $15000 \times \mathrm{g}$. The absorbance was measured at $280 \mathrm{~nm}$ in a spectrophotometer. Lignin content was expressed in $\mathrm{OD}_{280}$ units obtained from $10 \mathrm{mg}$ of dry matter.

Statistics. All results are presented as means \pm S.D. (standard deviation) obtained from nine independent replicates derived from tree independent biological experiments.

\section{RESULTS}

\section{Effects of cadmium and lead on steady-state level of PAL mRNAs and activity PAL enzyme in soybean and lupine}

The relative transcript levels of $P A L$ mRNA were established by semi-quantitative reverse transcription PCR (RT-PCR) of RNA isolated from roots incubated for 48 $\mathrm{h}$ in control conditions or in the presence of increasing concentrations of either $\mathrm{Cd}^{2+}$ (Figs. $1 \mathrm{~A}$ and $2 \mathrm{~A}$ ) or $\mathrm{Pb}^{2+}$ (Figs. $1 \mathrm{~B}$ and $2 \mathrm{~B}$ ). PAL mRNA amount was normalized to that of a housekeeping gene (ubiquitin - Ub) mRNA.

The PAL mRNA level was higher in soybean roots growing in the presence of $\mathrm{Cd}^{2+}$ (Fig. 1A) or $\mathrm{Pb}^{2+}$ (Fig. 1B) than in the control. The highest amount of mRNA coding for PAL was observed in the presence of $15 \mathrm{mg} / 1$ of $\mathrm{Cd}^{2+}$ or $50 \mathrm{mg} / 1$ of $\mathrm{Pb}^{2+}$. At the higher metal concentrations $\left(20-25 \mathrm{mg} / 1\right.$ of $\mathrm{Cd}^{2+}, 150-350 \mathrm{mg} / 1$ of $\mathrm{Pb}^{2+}$ ) (Figs. $1 \mathrm{~A}$ and $1 \mathrm{~B}$ ) the amount of $\mathrm{PAL}$ mRNA returned to the control value (for $\mathrm{Cd}^{2+}$ ) or to a value by only $34 \%$ above the control one (for $\mathrm{Pb}^{2+}$ ).

The activity of PAL was increased in soybean treated with $\mathrm{Cd}^{2+}$ or $\mathrm{Pb}^{2+}$ (Figs. 1A and 1B). The activity was strongly stimulated in roots exposed to $\mathrm{Cd}^{2+}$ and this effect was dose-dependent (Fig. 1A). At the highest concentration of $\mathrm{Cd}^{2+}(25 \mathrm{mg} / \mathrm{l})$ the activity was almost three times higher than in the control plants. The PAL activity was also increased in $\mathrm{Pb}^{2+}$-treated soybean roots. It reached the highest level, about $70 \%$ higher than in control plants, in the presence of the highest concentration of $\mathrm{Pb}^{2+}(350 \mathrm{mg} / \mathrm{l})$ (Fig. 1B).

The amount of $P A L$ mRNA was decreased in lupine seedlings treated with $\mathrm{Cd}^{2+}$ as compared to the control. 
A-1

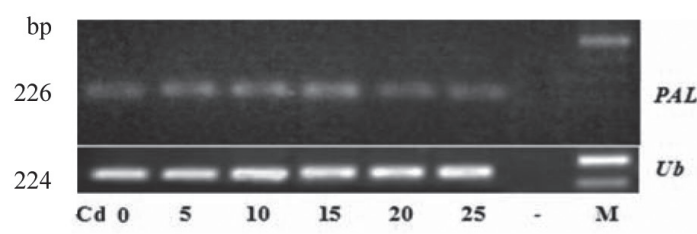

A-2

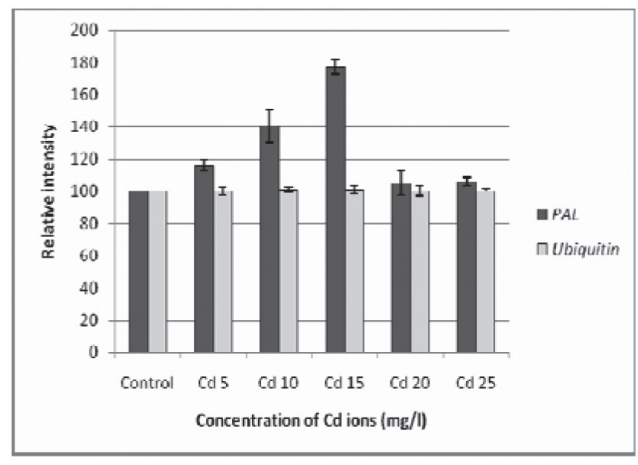

A-3

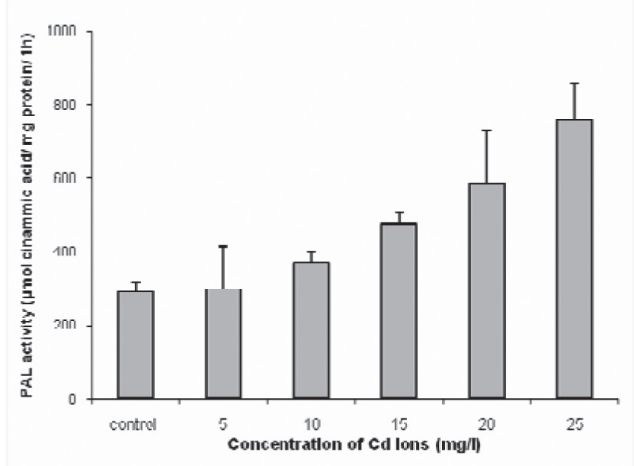

B -1

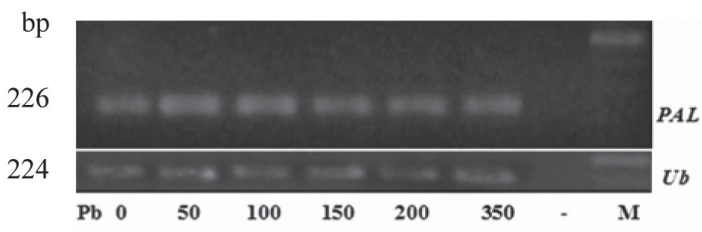

B -2

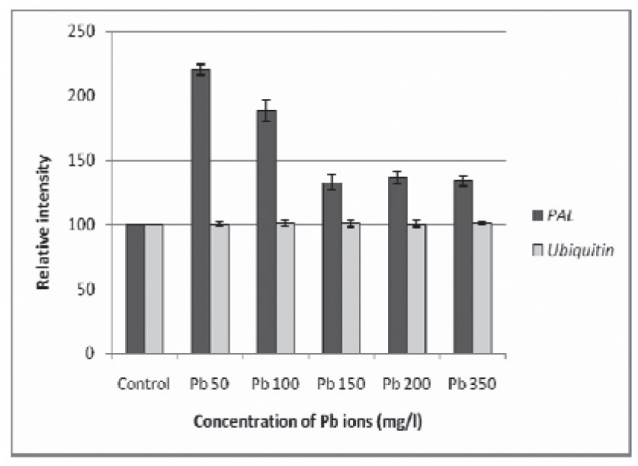

B - 3

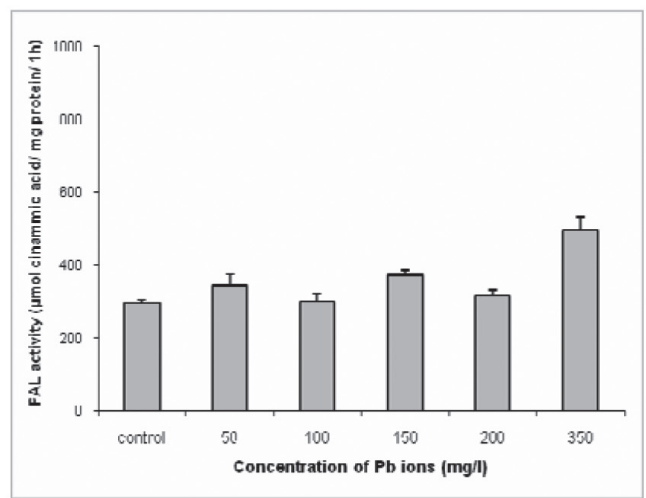

Figure 1. PAL mRNA level and phenylalanine ammonia-lyase (PAL) activity in roots of soybean seedlings treated with various concentrations of $\mathrm{Cd}^{2+}$ or $\mathrm{Pb}^{2+}$.

(A) Treatment with $\mathrm{Cd}^{2+}(0-25 \mathrm{mg} / \mathrm{l})$; (B) Treatment with $\mathrm{Pb}{ }^{2+}(0-350 \mathrm{mg} / \mathrm{l})$; PAL mRNA level: A-1, A-2, B-1, B-2; PAL activity: A-3, B-3. One microgram of total RNA from each tissue sample was used in RT-PCR with primers specific for PAL and ubiqutin genes. Products were separated on $2 \%$ agarose gels, stained with ethidium bromide (A-1, B-1) and quantified by densitometry (A-2, B-2). The intensities of individual bands were compared with the control sample as a point of reference (100\%). M - marker DNA (O'RangeRuler ${ }^{\mathrm{TM}} 100$ bp DNA Ladder, Fermentas). Values are means \pm S.D. of three independent experiments.

The observed inhibitory effect was most pronounced at the highest metal concentration $\left(25 \mathrm{mg} / \mathrm{l}\right.$ of $\mathrm{Cd}^{2+}$; Fig. $2 \mathrm{~A})$. In contrast $\mathrm{Pb}^{2+}$ treatment led to the accumulation of $P A L$ transcript. However, this effect was only detected at medium $\mathrm{Pb}^{2+}$ concentrations (150-200 mg/1 of $\left.\mathrm{Pb}^{2+}\right)$. At the highest $\mathrm{Pb}^{2+}$ concentration $(350 \mathrm{mg} / \mathrm{l}$ of $\mathrm{Pb}^{2+}$ ) the PAL mRNA level was below that of control (Fig. 2B).

The activity of PAL was stimulated in lupine roots treated with $\mathrm{Cd}^{2+}$ or $\mathrm{Pb}^{2+}$ (Figs. $2 \mathrm{~A}$ and $2 \mathrm{~B}$ ). The highest activity of the enzyme was observed in lupine roots exposed to $25 \mathrm{mg} / \mathrm{l}$ of $\mathrm{Cd}^{2+}$ or $150 \mathrm{mg} / \mathrm{l}$ of $\mathrm{Pb}^{2+}$. At the highest concentration of $\mathrm{Cd}^{2+}(25 \mathrm{mg} / \mathrm{l})$ the PAL activity in lupine roots was increased by about $40 \%$, whereas $\mathrm{Pb}^{2+}(150 \mathrm{mg} / \mathrm{l})$ caused the stimulation of the enzyme activity by about $50 \%$ (Figs. $2 \mathrm{~A}$ and $2 \mathrm{~B}$ ).

\section{Effects of cadmium and lead on lignin content in soybean and lupine}

Lignin content was analyzed in roots of soybean (Fig. 3A) and lupine (Fig. 3B) seedlings treated for $48 \mathrm{~h}$ with selected concentrations of $\mathrm{Cd}^{2+}(10$ or 25 $\mathrm{mg} / \mathrm{l})$ or $\mathrm{Pb}^{2+}(150$ or $350 \mathrm{mg} / \mathrm{l})$. The effect of the heavy metals on lignin accumulation was opposite in the analyzed plant species. The treatment of soybean with $\mathrm{Cd}^{2+}$ or $\mathrm{Pb}^{2+}$ caused a significant, 2 -fold, increase in lignin content, except for the lower concentration of $\mathrm{Pb}^{2+}(150 \mathrm{mg} / \mathrm{l})$ where it remained at the control level. In contrast, in $\mathrm{Cd}^{2+}$ or $\mathrm{Pb}^{2+}$-treated lupine roots lignin level was decreased. This effect was more pronounced at the higher concentrations of the heavy metals $\left(25 \mathrm{mg} / 1\right.$ of $\mathrm{Cd}^{2+}$ and $350 \mathrm{mg} / 1$ of $\mathrm{Pb}^{2+}$; Figs. $3 \mathrm{~A}$ and $3 \mathrm{~B})$. 
A -1

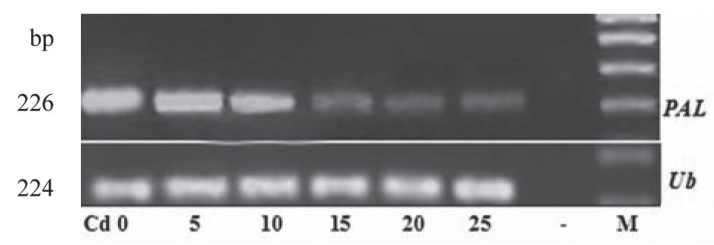

A -2

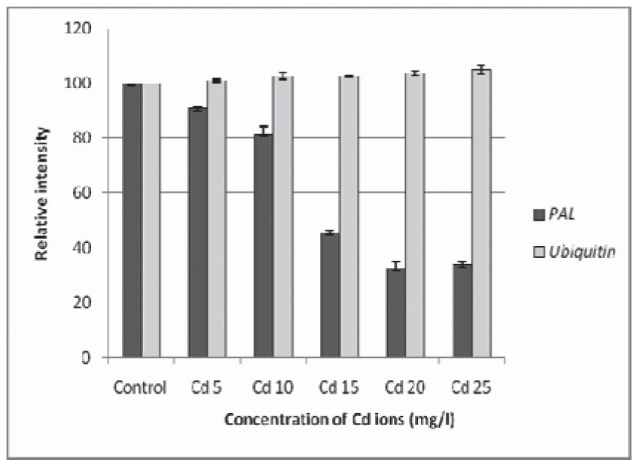

A -3

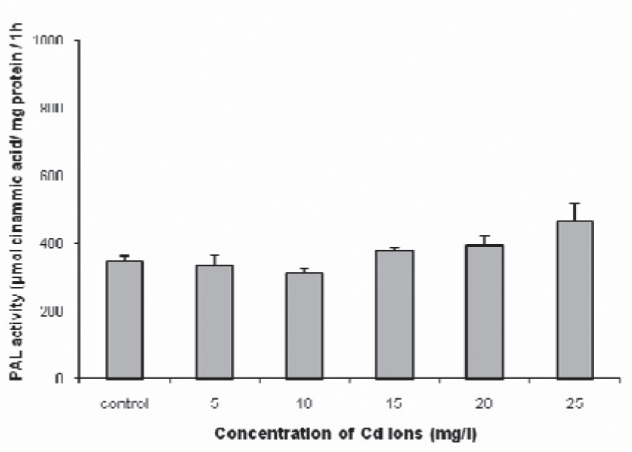

\section{B -1}

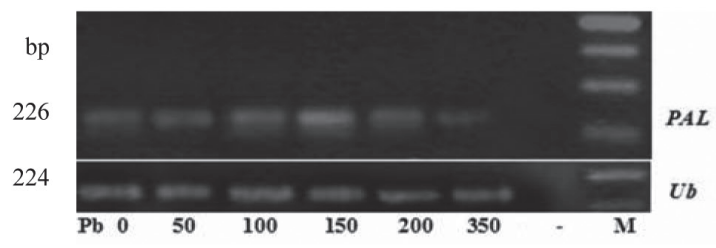

B -2

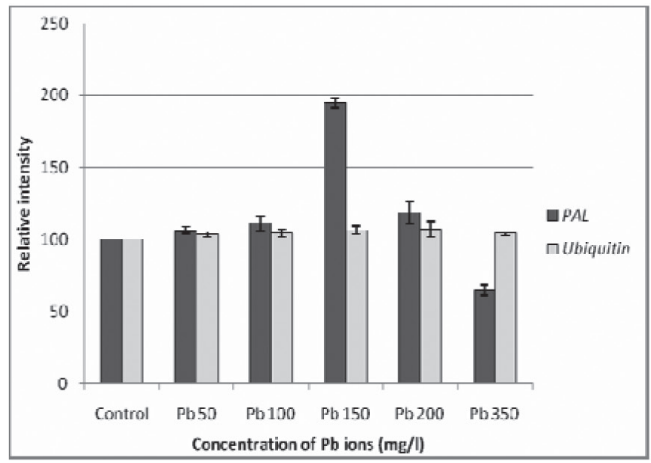

B -3

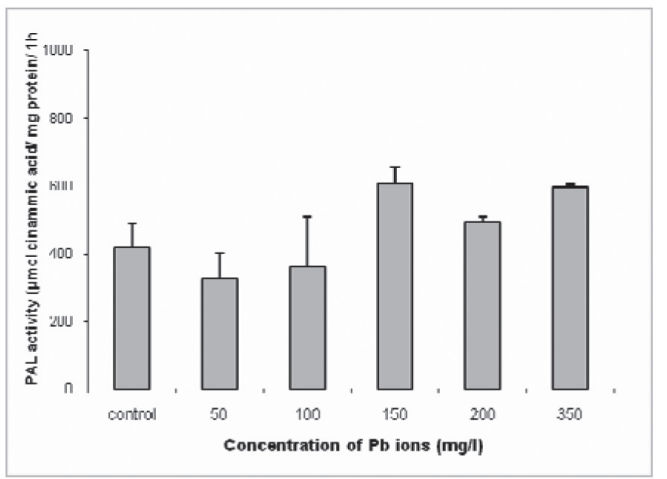

Figure 2. PAL mRNA level and phenylalanine ammonia-lyase (PAL) activity in roots of lupine seedlings treated with various concentrations of $\mathrm{Cd}^{2+}$ or $\mathrm{Pb}^{2+}$

(A) Treatment with Cd ${ }^{2+}(0-25 \mathrm{mg} / \mathrm{l})$; (B) Treatment with $\mathrm{Pb}^{2+}(0-350 \mathrm{mg} / \mathrm{l})$; PAL mRNA level: A-1, A-2, B-1, B-2; PAL activity: A-3, B-3. One microgram of total RNA from each tissue sample was used in RT-PCR with primers specific for PAL and ubiqutin genes. Products were separated on $2 \%$ agarose gels, stained with ethidium bromide (A-1, B-1) and quantified by densitometry (A-2, B-2). The intensities of individual bands were compared with the control sample as a point of reference (100\%). M - marker DNA (O'RangeRuler ${ }^{\mathrm{TM}} 100$ bp DNA Ladder, Fermentas). Values are means \pm S.D. of three independent experiments.

\section{DISCUSSION}

In this study we analyzed cadmium- and lead-induced changes in the expression and activity of the key phenylpropanoid pathway enzyme (PAL) and lignin content in roots of soybean (Glycine max) and lupine (Lupinus luteus) seedlings. Both $\mathrm{Cd}^{2+}$ and $\mathrm{Pb}^{2+}$ affected $P A L$ mRNA level in the analyzed plants (Fig. 1). The stimulatory effect of both metals was observed in case of mRNA coding for PAL in soybean. In the case of lupine, the changes of $P A L$ mRNA level were dependent on the metal used: $\mathrm{Cd}^{2+}$ caused a decrease, whereas $\mathrm{Pb}^{2+}$ an increase of $P A L$ transcript level. Transcription activation of $P A L$ genes has been observed in various plant species affected by different environmental stress factors (Dixon et al., 2002; Winkel-Shirley, 2002; Taiz \& Zeiger, 2006). In contrast, inhibition of $P A L$ expression is a less known plant response to unfavorable conditions. So far the de- crease of PAL mRNA has been described in fresh-cut endive (Cichorium intybus) subjected to heat shock (Salman et al., 2008) and in tea plants (Camellia sinensis) under drought stress (Singh et al., 2009).

PAL activity was increased in both plant species treated with $\mathrm{Cd}^{2+}$ or $\mathrm{Pb}^{2+}$. However, even when the level of $P A L$ mRNA was increased as well, the two responses were not co-ordinated. The highest enzyme activity was observed in soybean and lupine treated with higher concentrations of the metals $\left(25 \mathrm{mg} / 1\right.$ of $\mathrm{Cd}^{2+}$ or $150-350$ $\mathrm{mg} / \mathrm{l}$ of $\mathrm{Pb}^{2+}$; Figs. $1 \mathrm{~A}, 1 \mathrm{~B}$ and $\left.2 \mathrm{~A}, 2 \mathrm{~B}\right)$. The highest $P A L$ transcript level in soybean was detected at medium concentrations of both metals $\left(15 \mathrm{mg} / 1\right.$ of $\mathrm{Cd}^{2+}$ or $50-$ $100 \mathrm{mg} / 1$ of $\mathrm{Pb}^{2+}$ ) (Figs. 1A and 1B). These data indicate that lower concentrations of $\mathrm{Cd}^{2+}$ or $\mathrm{Pb}^{2+}$ are most effective in inducing $P A L$ in soybean at the transcript level, whereas higher concentrations of the metals are needed to affect PAL expression post-transcriptionally, 
A)

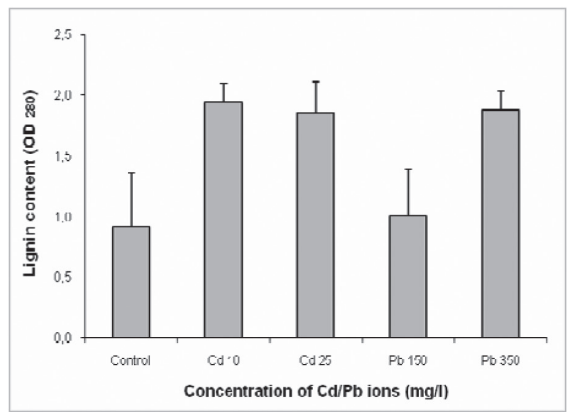

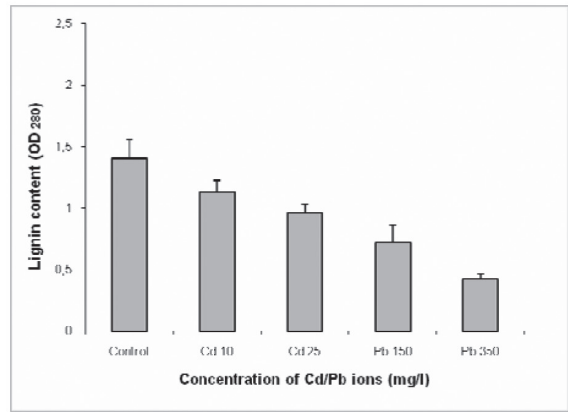

Figure 3. Lignin content in roots of soybean (A) and lupine (B) seedlings treated for $48 \mathrm{~h}$ with selected concentrations of Cd2+ or $\mathrm{Pb}^{2+}$.

Values are means \pm S.D. of three independent experiments.

at the level of the enzyme activity. The post-transcriptional mode of PAL regulation may play a major role in the case of $\mathrm{Cd}^{2+}$-treated lupine roots, where actually a decrease in the transcript level was correlated with enhanced enzyme activity (Fig. 2A). The PAL activity is known to be affected by various stress factors (Dixon \& Paiva, 1995; Booker \& Miller, 1998; Sarma \& Sharma, 1999). Stimulation of PAL activity has already been noted in plants exposed to copper and cadmium (Jouili \& Ferjani, 2003; Kovacik \& Klejdus, 2008). However, to our knowledge, $\mathrm{Cu}^{2+}$ and $\mathrm{Cd}^{2+}$ were the only metals whose effects on the phenylpropanoid pathway were analyzed so far. Our results indicate that in legume plants other heavy metals, such as $\mathrm{Pb}^{2+}$, also activate the expression of PAL at the level of transcription and posttranscriptionally.

It is generally accepted that the common plant responses to stress factors involve an enhancement of PAL activity and an increase of lignin content (Cahill \& McComb, 1992; Jbir et al., 2001; Mandre, 2002; Jouili \& Ferjani, 2003; Cabané et al., 2004; Lee et al., 2007). An increased lignin accumulation was reported in pepper and soybean treated with $\mathrm{Cu}^{2+}$ or $\mathrm{Cd}^{2+}$ (Diaz et al., 2001; Lin et al., 2005; Yang et al., 2007). However, our present data indicate that lignin synthesis is not a universal plant response to heavy metals. Our results confirmed that treatment of soybean seedlings with $\mathrm{Cd}^{2+}$ or $\mathrm{Pb}^{2+}$ caused an enhancement of lignin level. In contrast, lupine roots showed a decreased lignin content in response to either of the two heavy metals (Fig. 3B). Therefore, the increase of $P A L$ expression in lupine exposed to heavy metals could lead to the synthesis of secondary metabolites which are not involved in lignin formation. It was shown that treatment of soybean with $\mathrm{Hg}^{2+}$ is correlated with increased level of the glyceollins (Mithöfer et al., 2004), while in $\mathrm{Cu}^{2+}$-treated white lupine elevated levels of genistein and 2'-hydroxygenistein were observed (Gagnon \& Ibrahim, 1997). Based on this information and data presented here, we can conclude that heavy metal stress imposed by $\mathrm{Cd}^{2+}$ or $\mathrm{Pb}^{2+}$ causes induction of the phenylpropanoid pathway in soybean and lupine. The heavy metal-induced stimulation of this pathway in soybean is correlated with increased lignin content. In contrast, in lupine seedlings under the same conditions a decrease in lignin accumulation is observed, which suggests that PAL activation is involved in the synthesis of secondary metabolites other than lignin. The nature and the function of the secondary metabolites induced in lupine in response to heavy metals need to be elucidated.
Our accompanying paper (Pawlak-Sprada et al., 2011) addresses this question. Taken together, our data suggest that species-specific metabolic pathways are activated in legume plants exposed to heavy metals stress.

\section{Acknowledgements}

This study was partially supported by the Ministry of Science and Higher Education (grant N304 077635).

\section{REFERENCES}

Booker FL, Miller JE (1998) Phenylpropanoid metabolism and phenolic composition of soybean [Glycine max (L.) Merr] leaves following exposure to ozone. J Exp Bot 49: 1191-1202.

Cabané M, Pireaux JC, Léger E, Weber E, Dizengremel P, Pollet B, Lapierre C (2004) Condensed lignins are synthesized in poplar leaves exposed to ozone. Plant Physiol 134: 586-594.

Cahill DM, McComb JA (1992) A comparison of changes in phenylalanine ammonia-lyase activity, lignin and phenolic synthesis in roots of Eucalyptus calophylla (field resistant) and E. marginata (susceptible) when infected with Phytophtora cinnamoni. Physiol Mol Plant Pathol 40: $315-332$.

Clemens S (2001) Molecular mechanisms of plant metal tolerance and homeostasis. Planta 212: 475-486.

Cobbett C, Goldsbrough P (2002) Phytochelatins and metallothioneins: roles in heavy metal detoxification and homeostasis. Ann Rev Plant Biol 53: 159-182.

Das P, Samantaray S, Rout GR (1997) Studies on cadmium toxicity in plants: A review. Envir Pollut 98: 29-36.

Deckert J (2005) Cadmium toxicity in plants: Is there any analogy to its carcinogenic effect in mammalian cells? BioMetals 18: 475-481.

Deckert J, Gwóźdź EA (1999) The effect of lead on cyclin expression in lupine roots. Acta Physiol Plant 21: 249-256.

Diaz J, Bernal A, Pomar F, Merino F (2001) Induction of shikimate dehydrogenase and peroxidase in pepper (Capsicum annum L.) seedling in response to copper stress and its relation to lignification. Plant Sci 161: 179-188.

Dixon RA, Paiva NL (1995) Stress-induced phenylpropanoid metabolism. Plant Cell 7: 1085-1097.

Dixon RA, Achnine L, Kota P, Liu Ch-J, Reddy MSS, Wang L (2002) The phenylpropanoid pathway and plant defence - a genomics perspective. Mol Plant Pathol 3: 371-390.

Doster MA, Bostock PM (1988) Quantification of lignin formation in almond bark in response to wounding and infection by Phytophtotra species. Phytopathol 78: 473-477.

Fusco N, Micheletto L, Dal Corso G, Borgato L, Furini A (2005) Identification of cadmium-regulated genes by cDNA-AFLP in the heavy metal accumulator Brassica juncea L. J Exp Bot 56: 3017-3027.

Gagnon H, Ibrahim RK (1997) Effects of various elicitors on the accumulation and secretion of isoflavonoids in white lupin. Phytochemistry 44: 1463-1467.

Hahlbrock H, Scheel D (1989) Physiology and molecular biology of phenylpropanoid metabolism. Ann Rev Plant Physiol 62: 31-35.

Janas KM, Cvikrova M, Pałagiewicz A, Szafrańska K, Posmyk MM (2002) Constitutive elevated accumulation of phenylpropanoids in soybean roots at low temperature. Plant Sci 163: 369-373. 
Jbir N, Chaib W, Amma S, Jemmali A, Ayadi A (2001) Root growth and lignification of two wheat species differing in their sensitivy to $\mathrm{NaCl}$, in response to salt stress. CR Acad Sci Paris 324: 863-868.

Jouili H, Ferjani EE (2003) Changes in antioxidative and lignifying enzyme activities in sunflower roots (Heliantthus annus L.) stressed with copper excess. CR Biologies 326: 639-644.

Kovacik J, Klejdus B (2008) Dynamics of phenolic acids and lignin accumulation in metal-treated Matricardia chamomilla roots. Plant Cell Rep 27: 605-615

Lee B-R, Kim K-Y, Jung W-J, Avice J-C, Ourry A, Kim T-H (2007) Peroxidases and lignification in relation to the intensity of waterdeficit stress in white clover (Trifolium repens L.) J Exp Bot 58: 12711279 .

Lin Ch-Ch, Chen L-M, Liu Z-H (2005) Rapid effect of copper on lignin biosynthesis in soybean roots. Plant Sci 168: 855-861.

Mandre M (2002) Relationships between lignin and nutrients in Picea abies L. under alkaline air pollution. Water Air Soil Poll 133: 361-377.

Mithöfer A, Schulze B, Boland W (2004) Biotic and heavy metal stress response in plants: evidence for common signals. FEBS Lett 566: $1-5$.

Patra M, Bhowmik N, Bandopadhyay B, Sharma A (2004) Comparison of mercury, lead and arsenic with respect to genotoxic effects on plant systems and the development of genetic tolerance. Env Exp Bot 52: 199-223.

Pawlak S, Firych A, Rymer K, Deckert J (2009) Cu,Zn-superoxide dismutase is differently regulated by cadmium and lead in roots of soybean seedlings. Acta Physiol Plant 31: 741-747.

Pawlak-Sprada S, Stobiecki M, Deckert J (2011) Activation of phenylpropanoid pathway in legume plants expose to heavy metals: Part II. Profiling of isoflavonoids and their glycoconjugates induced in roots of lupine (Lupinus luteus) seedlings treated with cadmim and lead. Acta Biochim Pol 58: 217-223.

Przymusiński R, Gwóźdź EA (1999) Heavy metal-induced polypeptides in lupin roots are similar to pathogenesis-related proteins. I Plant Physiol 154: 703-708.

Roth U, von Roepenack-Lahaye E, Clemens S (2006) Proteome changes in Arabidopsis thaliana roots upon exposure to $\mathrm{Cd}^{2+}$.J Exp Bot 57: 4003-4013.

Rucińska R, Waplak S, Gwóźdź EA (1999) Free radical formation and activity of antioxidant enzymes in lupine roots exposed to lead. Plant Physiol Biochem 37: 187-194.

Rucińska R, Sobkowiak R, Gwóźdź EA (2004) Genotoxicity of lead in lupin root cells as evaluated by the comet assay. Cell Mol Biol Lett 9: $519-528$.
Salman A, Goupil P, Filgueiras H (2008) Controlled atmosphere and heat shock affect PAL1 and HSP90 mRNA accumulation in freshcut endive (Cichorium intybus L.). Eur Food Res Technology 227: 721726.

Sandalio LM, Dalurzo HC, Gomez M, Romero-Puertas MC, del Rio LA (2001) Cadmium-induced changes in growth and oxidative metabolism of pea plant. I Exp Bot 52: 2115-2126.

Sarma AD, Sharma R (1999) Purification and characterization of UVB-induced phenylalanine ammonia-lyase from rice seedlings. Phytochemistry 50: 729-737.

Seregin IV, Ivanov VB (2001) Physiological aspects of cadmium and lead toxic effects on higher plants. Russ J Plant Physiol 48: 523-544.

Sharma P, Dubey RS (2005) Lead toxicity in plants. BrazJ Plant Physiol 17: $35-52$.

Shingu Y, Kudo T, Ohsato S, Kimura M, Ono Y, Yamahuchi I, Hamamoto H (2005) Characterization of genes encoding metal tolerance proteins isolated from Nicotiana glauca and Nicotiana tabacum. Biochem Biophys Res Comm 331: 675-680.

Singh K, Kumar S, Rani A, Gulati A, Ahuja PS (2009) Phenylalanine ammonia-lyase (PAL) and cinnamate 4-hydroxylase $(\mathrm{C} 4 \mathrm{H})$ and catechins (flavan-3-ols) accumulation in tea. Funct Integr Genomic 9: 125-134.

Sobkowiak R, Deckert J (2003) Cadmium-induced changes in growth and cell cycle gene expression in suspension-culture cells of soybean. Plant Physiol Biochem 41: 767-772.

Sobkowiak R, Deckert J (2004) The effect of cadmium on cell cycle control in suspension culture cells of soybean. Acta Physiol Plant 26: 335-344.

Sobkowiak R, Deckert J (2006) Proteins induced by cadmium in soybean cells. J Plant Physiol 163: 1203-1206.

Sobkowiak R, Rymer K, Rucińska R, Deckert J (2004) Cadmium-induced changes in antioxidant in suspension culture of soybean cells. Acta Biochim Pol 51: 219-222.

Srivastava AK, Venkatachalam P, Raghothama KG, Sahi SV (2007) Identification of lead-regulated genes by suppression subtractive hybridization in the heavy metal accumulator Sesbania drummondii. Planta 225: 1353-1365

Taiz L, Zeiger E (2006) Plant Physiology. 4th edn, pp 315-341. Sinauer Associates, Inc. Publisher, Sunderland, Massachusetts, USA.

Winkel-Shirley B (2002) Biosynthesis of flavonoids and effects of stress. Curr Opin Plant Biol 5: 218-223.

Yang Y-J, Cheng L-M, Liu Z-H (2007) Rapid effect of cadmium on lignin biosynthesis in soybean roots. Plant Sci 172: 632-637. 